УДК 330.3

DOI $10.21661 / \mathrm{r}-115527$

\title{
Р.Ф. Шамсиева
}

\section{БАНКРОТСТВО ПРЕДПРИЯТИЯ: ОСНОВНЫЕ ПРИЧИНЫ ВОЗНИКНОВЕНИЯ И ПУТИ ВЫХОДА}

Аннотация: в статье рассмотрены причины несостоятельности предприятий, выявлены проблемы, связанные с применением зарубежных и российских моделей диагностики банкротства. Рассмотрены направления деятельности, способствующие выводу предприятия из кризисного состояния.

Ключевые слова: банкротство, несостоятельность, кризисное состояние, диагностика банкротства, антикризисное управление.

\section{R.F.Shamsieva}

\section{THE ENTERPRISE BANKRUPTCY: MAJOR CAUSES}

\section{AND WAYS TO SOLVE IT}

Abstract: the article examines the causes of insolvency of enterprises, the problems associated with use of foreign and Russian models of bankruptcy diagnostics are discovered. The activities that help the enterprise to solve the crisis are described.

Keywords: bankruptcy, insolvency, crisis, bankruptcy diagnosis, crisis management.

В реалиях нестабильного развития экономики России, обусловленных как внутренними политическими, социально-историческими, так и внешними (политическими, экономическими) факторами, проблемы управления предприятиями, находящимися в кризисных условиях, становятся особенно актуальными.

Поэтому вопросы, связанные с выявлением неблагоприятных тенденций развития предприятия, прогнозированием кризисной ситуации и банкротства, антикризисным управлением вызывают интерес у многих ученых и специали- 
стов, занимающихся проблемами управления финансами и финансовым состоянием предприятия.

Определение понятия «банкротство» споров не вызывает и трактуется однозначно. Тем более, что законодательство дает четкое определение данного понятия: «под несостоятельностью (банкротством) понимается признанная арбитражным судом или объявленная должником неспособность предприятия в полном объеме удовлетворить требования кредиторов по денежным обязательствам и исполнить обязанность по уплате обязательных платежей».

Причины, подводящие предприятие к кризисному состоянию, могут быть различными. При этом единой общепризнанной классификации причин наступления несостоятельности предприятия не существует.

Анализ трудов разных ученых позволяет выявить несколько групп причин: ухудшение финансового состояния предприятия, вызванное недостаточным объемом собственных средств предприятия и отказом кредитных организаций в дальнейшем финансировании, неэффективным управлением активами, снижением конкурентоспособности выпускаемой продукции. К подобным последствиям приводят ошибки руководства, допущенные в ведении хозяйственной деятельности. Некоторые авторы называют их как один из ведущих факторов банкротства [3, с. 99]. Ряд ученых считают наиболее важными внешние по отношению к предприятию факторы. В частности, О.А. Львова и О.М. Пеганова отмечают, что среди экономических предпосылок банкротства следует выделить цикличность экономического развития [2, с. 65].

Диагностика банкротства предприятия требует проведения фундаментальной диагностики финансового состояния предприятия; анализа рыночной ситуации; обнаружения симптомов причин и основных факторов, способствующих развитию кризисной ситуации; прогнозирования масштабов кризисного состояния предприятия и может проводиться с применением различных методик.

Единой методики диагностики банкротства, признанной на законодательном уровне и применимой для всех предприятий в России, не существует. Бо- 
лее того, известные методики требуют осторожного отношения к процессу диагностики.

Хотя справедливости ради надо отметить, что законодательством установлен круг показателей, которые должны быть рассчитаны до начала процедуры банкротства. Это такие финансовые коэффициенты, как: коэффициент текущей ликвидности, обеспеченности собственными средствами и восстановления (утраты) платежеспособности. При этом предприятие признается неплатежеспособным, если коэффициент текущей ликвидности на конец отчетного периода имеет значение менее 2, коэффициент обеспеченности собственными средствами на конец отчетного периода имеет значение менее 0,1 .

Опыт зарубежных ученых в области предсказания банкротства предприятий позволяет сделать вывод о том, что из множества финансовых показателей можно выбрать лишь несколько полезных и более точно предсказывающих банкротство. За много лет развития института банкротства за рубежом созданы различные методики диагностики банкротства: модель Бивера, основывающаяся на расчете четырех финансовых показателей, дискриминативные факторные модели Альтмана, Лиса, Таффлера, Фулмера, Спрингейта, Ольсона и др.

Однако почти двадцатилетние попытки применения иностранных моделей прогнозирования банкротства в отечественных условиях не принесли достаточно точных результатов. Причины тому называет Ю.А. Чурсина. Это: несопоставимость факторов, генерирующих угрозу банкротства; различия в учете отдельных показателей; влияние инфляции на их формирование; несоответствие балансовой и рыночной стоимости отдельных активов и др. объективные причины [4, с. 157].

В связи с этим были предложены различные способы адаптации «импортных» моделей к российским хозяйственным условиям. Можно отметить следующие модели: модель О.П. Зайцевой, модель Р.С. Сайфуллина и Г.Г. Кадыкова, модель Иркутской ГЭА, модель А.В. Колышкина и др.

Но данные модели тоже несовершенны и могут применяться в практике диагностики банкротства предприятия с некоторыми оговорками. Проблемы, связанные с применением данных моделей следующие. Отсутствие в РФ статистических материалов по организациям-банкротам не позволяет скорректиро- 
вать методику исчисления весовых коэффициентов и пороговых значений с учетом российских экономических условий, а определение данных коэффициентов экспертным путем, не обеспечивает их достаточной точности. Институт банкротства в нашей стране еще очень молод, что затрудняет разработки, направленные на достоверное прогнозирование возможного банкротства предприятий. Еще одной проблемой является то, что методики учитывают состояние показателей лишь на момент анализа, а изменения динамики показателей во времени не рассматриваются. Между тем, изучение динамики состояния предприятия и выявление возможной кризисной ситуации заранее, еще до появления очевидных признаков, как отмечает Т.М. Жукова, является залогом успешного применения антикризисных мер [1, с. 203].

Кроме того, прогностическая способность модели с течением времени может меняться: методики эффективно могут применяться только для предприятий той группы и в экономической ситуации того периода, для которых они были изначально разработаны.

По результатам диагностики финансового состояния руководство предприятия должно предпринять меры по предотвращению банкротства, которые связаны с эффективным управлением его финансами и производством, правильным определением стратегических целей и тактики их реализации.

При угрозе банкротства финансовый менеджмент должен быть направлен на реализацию следующих принципиальных целей: обеспечение финансового оздоровления предприятия за счет реализации внутренних резервов хозяйственной деятельности; обеспечение финансового оздоровления предприятия за счет внешней помощи и частичной его реорганизации; прекращение хозяйственной деятельности и начало процедуры банкротства.

Соответственно этим целям формируются и система механизмов финансового управления предприятием, которая включает: внедрение внутренних механизмов финансовой стабилизации предприятия; совершенствование системы внутреннего контроля; выбор эффективных форм санации предприятия.

Таким образом, под несостоятельностью понимается неспособность предприятия в полном объеме удовлетворить требования кредиторов по денежным обязательствам и исполнить обязанность по уплате обязательных платежей. 
При прогнозировании финансового состояния предприятия с позиции возможного банкротства используют модели, разработанные как зарубежными, так и российскими специалистами. Меры по предотвращению банкротства предприятия связаны с эффективным управлением его финансами и производством, правильным определением стратегических целей и тактики их реализации.

\section{Сиисок литературы}

1. Жукова Т.М. Современные особенности применения экономических моделей диагностики вероятности наступления банкротства юридических лиц / Т.М. Жукова, К.С. Кондратьева // Вестник Пермского университета: Юридические науки. - 2014. - №1. - С. 197-205.

2. Львова О.А. Факторы и причины банкротства компаний в условиях современной экономики / О.А. Львова, О.М. Пеганова // Государственное управление: Электронный вестник. - 2014. - №44. - С.64-82.

3. Ряховская А.Н. Антикризисное управление в современных условиях: Проблемы, направления, решения // Имущественные отношения в РФ. - 2013. №6. - C. 20-24.

4. Чурсина Ю.А. Выявление эффективной методики диагностики банкротства предприятия в целях предупреждения введения антикризисного управления / Ю.А. Чурсина, К.В. Кондратьева // Аудит и финансовый анализ. - 2013. №1. - C. 153-159.

Шамсиева Регина Фаниловна - старший кассир ООО «Оптовик»; студентка ФГБОУ ВО «Башкирский государственный университет», Россия, Уфа.

Shamsieva Regina Fanilovna - senior cashier LLC "Optovik"; student FSFEI of HE “Bashkir State University”, Russia, Ufa. 